\title{
5. A clinical study of basti (kal-basti) in the management of katigata vatavyadhi w.s.r.t. Lumbar Spondylosis.
}

\author{
Dr.Gharge Archana, Address-3B/002, Chandivali Shraddha CHS. Ltd., Mhada Colony, Chandivali, Andheri \\ (E),Mumbai 400072. Designation-Associate Professor, Rog nidan \& Vikruti Vigyan Dept. \\ Dr. G. D. Pol Foundations YMT Ayurvedic Medical College, Kharghar) \\ E-mail ID-dr.archanapatil@ rediffmail.com Mobile no.-9821741702
}

\section{ABSTRACT}

Several studies have suggested an important role of Basti treatment in the asthimajjagata Vatavyadhi like katigata vata.Even the use of Panchatiktaghritakshir basti in same has been studied \& has proved best.But the use of Kal Basti(16 bastis) \& that Anuvasana Basti of which with Panchatiktaghrita instead of oil has not been studied earlier.This study was aimed to find the combined effect of basti \& Panchatiktaghrita in Asthimajjagata vatavyadhi like katigatavata (degenerative changes at lumbosacral region) together to give best results.

In thius study, 30 patients in the age group between 18 to 60 years in R.A.Podar College $\&$ hospital were selected randomly. Patients mainly complaining of Katishul,,Katigraha etc. \& showing osteophytes in their X-ray L.S.Spine s/o degenerative changes has been selected..The patients treated on IPD level who were given basti for the period of 16 days.

Students paired $\mathrm{T}$ test was used for interpretation of results. Positive significant symptomatic relief in patients was observed but there was no significant positive change in radiological findings i.e osteophytes in X-ray L.S.Spine after treatment.

Our study concluded that the basti treatment is significantly effective treatment in the management of katigatavatavyadhi giving symptomatic relief \& the use of panchatiktaghrita in anuvasana basti has proved more beneficial in asthimajjashrita vatavyadhi.

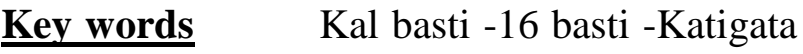
vatavyadhi-lumbar spondylosis

\section{Introduction}

Ageing is ongoing process along with degeneration in body systems. But todays fast food and altered life style is bringing the process of degeneration too early for the age. The incidence of degenerative changes in youngsters is alarming. Diseases related to musculo-skeletal system has high prevalence rate. The faulty dietary habits, extremes of sedentary life style or physical activity,wrong sitting posture ,continuous sitting work in software \& I.T.professionals are making the system prone to degeneration. It is resulting in development of degenerative diseases especially of vertebral column, most common being arthritis, spondylosis , PID ,low back pain etc.. Ayurveda recognises these disorders caused by Vata due to impairment of Asthi and Majjadhatu.

\section{"Asthyashrayanam vyadhinam panchakarmani bheshajam Bastayah kshirsarpishi tiktakophitani cha"1}

Panchakarma treatment is speciality of Ayurveda that provides rational solution for such diseases of which Basti is generally advocated in treatment of Vatavyadhis. Use of Pancha Tikta Ghrita in the basti Basti treatment is one of such classical combination of drugs that is useful in degenerative diseases of vertebral column described by ashtanghridaykars.In asthi majjagata vatavyadhis there are two main events creatiing samprapti i.e. asthi dhatukshaya \& vataprakopa.And according to our samhitas,vatadosha \& Asthidhatu have Ashrayashrayi sambanndh in which the the dravyas causing kshaya of vatadosha are ultimately responsible for asthi dhatu vriddhi \& vice a versa . Panchatikta ghrita (guggulyukta) 


\section{Ayurlog: National Journal of Research in Ayurved Science}

\section{A Web based quarterly online published peer reviewed National E-journal of Ayurveda.}

is having snigdha gunatmaka ghrita playing an important role in vatashamana \& tiktarasatmaka dravyas having kharatva \& shoshan properties similar to Asthidhatu,resulting in Asthidhatu vriddhi by samanen samanasya vriddhi nyaya.Guggulu itself is the best vatashamak dravya.So one such study on the effect of kal- Basti using panchatikta ghrita for anuvasana \& dashmul kwath for niruha, in degenerative diseases of vertebral column has been done $\&$ presented along with results in subjective and objective parameters.

\section{"Tatrasthani sthito vayuh"2}

"Yadekasya tadanyasya $\begin{array}{r}\text { vardhan } \\ \text { kshapanaushadham Asthi marutayoh }\end{array}$
naivam prayo vriddhirhi tarpanat"3

Basti upakram is mentioned as an important treatment for all vatvikaras.Vata is the motivating force in the body responsible for spreading other doshas (pitta \& kafa) in all tracts in the body.so ultimately in almost all diseases vata dosha is responsible. And basti is the main treatment to control vata. So basti has been described as fifty \% treatment(ardhi chikitsa) by Charakacharya.And in some sanhitas it is said to be a complete chikitsa for all vatavyadhis.

Katigata vatavyadhi is a vata disorder occurring at kati sandhi(i.e. lumbar intervertebral joints \& the asthis related with them i.e. lumbar vertebrae). Among many causes of katishool,one is denerative changes of lumbar vertebrae,i.e.lumbar spondylosis, osteoporotic changes of spine etc.). charakacharya has mentioned to give bastis of kshir \& ghrita medicated with tikta-rasatmak dravyas in asthigata vyadhis.and even ashtang hriday also has same reference in sutrasthan.

\section{"Asthisankshayat ,Jatan kshirghritae tiktasanyutae bastibhistatha" 4}

Pancha tikta ghrita is mentioned in vata vyadhi chikitsa, specially for asthi-majjagata vata \&sandhigata vata by Ashtang hridaykar With this reference in kala basti ,pancha tikta ghrita was used for anuvasana basti \&dashmul kwath for niruh basti in treatment.

\section{Material \& Methods}

Type of study - A clinical open study.

The clinical study was conducted at R.A.Podar college \& hospital,worli,Mumbai on IPD level \& 30 patients having chief complain of katishul(low back pain),katigraha and showing vertebral degenerative changes (osteophytes) in their X-ray lumbosacral region were included with a written consent Diagnosis was made on clinical symptoms \& radiological findings Patients having symptoms like katishul(low back pain),katigraha (stiffness in the lumbar region ), lumbar pain increased on movements i.e. forward \& backward bending,tingling \& numbness in one or both lower extremities\& showing denerative changes (osteophytes on lumbar vertebral bodies) s/o lumbar sponylosis in their X-ray of lumbo-sacral region were selected.Randomisation of patients from all socio-economic class in the age group between 18 to 60 years from hospital OPD was done.Patients having low back pain but following diseases during selection were excluded for research work.

\section{Exclusion criteria}

1.Patient with prolapsed intervertebral disc.

2. Patients with spinal canal stenosis,lumbar spondylo-lysthesis, ankylosing spondylitis,Pott's

spine ,curvature abnormalities of spine.

3. Sciatica patients with SLRT positive

4 Female patients with pelvic inflammatory diseases (PID) ,having gynaecological symptoms

alongwith low back pain.

5 Patients with severe systemic illness e.g. Hypertension,D.M.,Tuberculosis,cancer etc.

6 Patients having rheumatoid A.,rheumatic A., Gout.

\section{Investigations}

All routine investigations ( $\mathrm{CBC}, \mathrm{ESR}$, BSLrandom,Urine-R\&M, CXR-PA View)were done during patient selection. 


\section{Ayurlog: National Journal of Research in Ayurved Science}

A Web based quarterly online published peer reviewed National E-journal of Ayurveda.

Radiological study i.e. X-ray Lumbosacral region $-\mathrm{AP} /$ Lat view was done before $\&$ after the treatment.

Other tests- RA,ASO, S.uric acid were done to rule out the rheumatoid,rheumatic arthritis \& gout to exclude the patients with these conditions.

\section{Method of administration of the drug}

Treatment used-Patients were given Kal-basti for 16 days(Ref-Cha.siddhisthan 1/47,48chakrapani tika) Sequence of bastis was as follows- first one in Anuvasana, then alternately 6 Niruha \& 6 Anuvasana, \& finally 3 Anuvasana.

\section{Drug used}

For Anuvasana basti - Panchatikta ghrita was used in $60 \mathrm{ml}$. quantity which was prepared acc. to reference.of ashtanga Hriday vatavyadhichikitsa $21 / 58,59,60)$,in the rasshastra department of R.A.Podar college

For niruha basti - Medicated dashmul decoction in quantity of $500 \mathrm{ml}$. was used.

Anuvasana basti-Panchatikta ghrita (guggulyukta)-Reference

"Nimbamritavrishpatol nidigdhikanam,bhagan prithak dashpalanvipached hatepam,ashtanshasheshitrasen punascha ten prasthamghritasya vipached pichubhag kalkaeh,Patha vidang surdaru gajopkulya ,dviksharnagar nisha mishi chavya kushthaih,tejovati marich vatsak dipakagni ,rohinyushkar vacha kanamulyuktaih,Manjishtha ativisha visha yavanya,sashuddha guggul palairapi panchasankhaih,Tat sevitam vidhamati prabalam samiram, Sandhyasthi majjagatamapi atha kustham idruk"5

Niruha basti contents

Medicated decoction prepared by mixing the following ingredients in the same sequence as mentioned by Charakacharya.

"Madhusnehen kalkadhya kashayavapatah kramat (Ch.Sam.Si.3/30)"6

Honey - $50 \mathrm{ml}$,
Saindhav lavan -3 gms,

Til oil - $50 \mathrm{ml}$,

Kalka (dashmul \& madanphal) - 5 gms \& medicated decoction of dashmul $-400 \mathrm{ml}$ were mixed together to prepare niruha basti.

(Dashmul dravyas-

Bilva,Agnimantha,Shyonak,Kashmarya,Patli,S haliparni,Prishniparni,Brihati,Kantkari,Vardha nanak)7

\section{Basti kal}

Anuvasana was given in morning,immediately after having food \&

Niruha was also given in morning,after digestion of early night dinner \&after malamutrotsarga as per indication.

"Na tu bhuktavate deyam asthapanamiti sthitih"

"Bhojayitva yatha shastram krit chankramanam tatah visarjya cha shakrinmutram yojayet sneh bastina"8

\section{Follow up}

Daily examination of admitted patients to record disease symptoms \& to note the basti pratyagama kal, during treatment was done for 16 days.After discharge,follow ups after every 15 days for one month were taken to observe the symptoms.

\section{Clinical parameters for assessment of results}

\section{Subjective criteria}

Katishula(L.B.P.),

Katigraha,

Low back pain during forward \& backward bending

Tingling \&numbness in lower extremities

Adhman ,Malbaddhata were the subjective parameters

\section{Objective criteria}

osteophytes s/o denerative changes of spine in the X-ray L.S. spine was objective 


\section{Ayurlog: National Journal of Research in Ayurved Science \\ A Web based quarterly online published peer reviewed National E-journal of Ayurveda.}

parameter.Gradation of each symptom was done as mild,moderate\& severe to know the level of severity of disease.

Statistical analysis was done on the basis of these parameters.

\section{Criteria of relief in \%age}

With follow ups, study progress was observed $\&$ analysed to assess the benefit \& improvement of condition as .

Uttam upashaya -above $75 \%$,

Madhyam upashaya - 50 to $<75 \%$,

Heena upashaya $\quad-25$ to $<50 \%$,

Anupashaya $\quad-<25 \%$

By applying students paired ' $\mathrm{t}$ ' test the analysis was done $\&$ the result found statistically significant.

\section{$\underline{\text { Results }}$}

The mean age of study population was $13.33 \%$ in 21-30 age group,33.33\% in 31-40 age group, $33.33 \%$ in $41-50$ age group \& $20 \%$ in $51-$ 60 age group.Positive significant relief in patients symptoms was as follows-66.66\%in katishul $(\mathrm{p}<0.001), 83.33 \%$ in

katigraha $(\mathrm{p}<0.001), 77.27 \%$ in back pain during forward bending $(\mathrm{p}<0.001), \& 74.07 \%$ in back pain during backward bending $(\mathrm{p}<0.001)$, Tingling, numbness in lower extremities $(\mathrm{p}<0.001)$. Out of 30 patients, $18(60 \%)$ werw females \&12(40\%)were males. The patients having complains since 1 year were $8(26.66 \%), 2$ years were $11(36.66 \%), 2-5$ years were $8(26.66 \%)$ \&more than 5 years were $3(10 \%)$. There was no significant corelation between the symptomatic relief \& the changes in osteophytes in radiological examination.

\section{Discussion}

It can be concluded that the basti treatment is an exclusively effective treatment in the management of katigata vatavyadhi giving symptomatic relief. Considering the ashrayashrayi sambandh of vatadosha \& Asthidhatu as described in Ashtang samhita,panchatikta ghrita(guggulyukta) was selected as sneha dravya for Anuvasana basti. Tikta rasatmak dravyas, having shoshan \& kharatva property,must having a good role in asthi vardhan karma because of the same property(kharatva) of asthidhatu. Ghrita being snigdha, did good job in relieving viciated vatadosha It can be concluded that ,Panchatikta ghrita having combination of tikta rasa(kharatva property) \& ghrita(snigdha property) has an excellent role in asthigata vata vyadhi by asthiposhan and vatashaman,because there is not a dravya having both snigdha guna \& tikta rasa.

\section{Acknowledgement}

Author acknowledge all the staff of kayachikitsa IPD \& Panchakarma Department with special thanks to rasshastra department for kind co-operation in medicine preparation.

\section{References}

5. Agnivesha,Charaka samhita ,Revised by Charaka and dridhabala with Ayurved Dipika commentary of Chakrapanidutta Edited by Vaidya Yadavaji Trikamji Acharya,Chaumamba Sanskrit sansthan varanasi,fifth edition ,2001-Sutrasthana ,Adhyaya no.28.

6. Vagbhata,Ashtang Hridaya, with the commentaries "Sarvangsundar " of Arundatta \& Ayurvedarasayana of Hemadri ,Krishnadas academy,Varanasi,2000, Sutrasthana ,Adhyaya 11, shloka no 26.

7. Vagbhata,Ashtang Hridaya, with the commentaries "Sarvangsundar " of Arundatta \& Ayurvedarasayana of Hemadri ,Krishnadas academy,Varanasi,2000, Sutrasthana ,Adhyaya 11, shloka no27.

8. Vagbhata,Ashtang Hridaya, with the commentaries "Sarvangsundar " of Arundatta \& Ayurvedarasayana of Hemadri ,Krishnadas academy, Varanasi,2000, Sutrasthana ,Adhyaya 11, shloka no. 31(Arundatta tika ).

9. Vagbhata,Ashtang Hridaya, with the commentaries "Sarvangsundar " of Arundatta \& Ayurvedarasayana of Hemadri ,Krishnadas academy,Varanasi,2000, Chikitsasthana -Vatavyadhi chikitsa ,Adhyaya no . 21, shloka no. 58,59,60.

10. Agnivesha,Charaka samhita ,Revised by Charaka and dridhabala with Ayurved Dipika commentary of Chakrapanidutta Edited by Vaidya Yadavaji Trikamji Acharya,Chaumamba Sanskrit sansthan varanasi,fifth edition ,2001-Siddhisthana ,Adhyaya no.3,shloka no.31. 
Ayurlog: National Journal of Research in Ayurved Science

A Web based quarterly online published peer reviewed National E-journal of Ayurveda.

11. Agnivesha ,Charaka samhita ,Revised by Charaka and dridhabala with Ayurved Dipika commentary of Chakrapanidutta Edited by Vaidya Yadavaji Trikamji Acharya,Chaumamba Sanskrit sansthan varanasi,fifth edition ,2001-Siddhisthana ,Adhyaya no.3,shloka no.31.

12. Agnivesha,Charaka samhita, Revised by Charaka and dridhabala with Ayurved Dipika commentary of Chakrapanidutta Edited by Vaidya Yadavaji Trikamji Acharya,Chaumamba Sanskrit sansthan varanasi,fifth edition , 2001-Siddhisthana ,Adhyaya no.10,shloka no.19,20.

13. Sushrut samhita chikitsasthana,Adhyaya no. 37 , shloka no. 59.

14. Harrisons principles of Internal medicine, vol.2,Mc Grawihill companies.

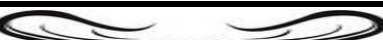

